\title{
Effect of Planting Dates on Growth and Yield of Sweet Potato (Ipomoea Batatas L) Genotypes
}

Sumi Dash, A.F.M Saiful Islam, Sharifunnessa Moonmoon

Department of Crop Botany and Tea Production Technology, Faculty of Agriculture, Sylhet Agricultural University, Sylhet-3100, Bangladesh

*Corresponding author: Sharifunnessa Moonmoon

\section{Abstract}

The present study was carried out in the farmer's field at Dashpara Sylhet and the research laboratory and farm of the Department of Crop Botany and Tea Production Technology at Sylhet Agricultural University, Sylhet. The study was carried out during October 2016 to May 2017 to study the effect of planting dates on growth and yield of sweetpotato (Ipomoea batatas L.) genotypes. The study was done under three planting date's viz. 10 October, 10 November and 10 December. Six genotypes evaluated in the study were Bangladeshi namely BSP-1(Tripti), BSP-2 (Kamalasundori), BSP-5, BSP-8, BSP-12 and Local-6. The experiment was laid out in a Randomized Completely Block Design (RCBD). The field was divided into 3 blocks for 3 replications. Data on the morphological characteristics, growth studies and yield parameters were recorded at 150 days after planting (DAP) at final harvest. Results revealed that the morphological characteristics, dry matter partitioning and yield attributing parameters varied among the genotypes and planting dates. From the present findings, it was found that better genotypes, which in regard to vegetative growth parameters gave low yields. The Local-6 genotype was grown vigorously but produced poor storage root. In respect of interaction effect, BSP-5 planted on 10 November showed the highest number of leaves (332.67) and total leaf area $\left(13727.60 \mathrm{~cm}^{2}\right.$ plant ${ }^{-1}$ ), whereas the same genotype planted on 10 October showed the lowest number of primary (2.00) and secondary (3.00) vines and the lowest number of leaves plant ${ }^{-1}$ (70.00). BSP-12 planted on 10 November showed maximum total fresh weight (1664.57 $\mathrm{g} \mathrm{plant}^{-1}$ ) after check genotype (1761.17 $\left.\mathrm{g} \mathrm{plant}^{-1}\right)$ and BSP-12 planted on 10 December 2016 showed maximum total dry weight $\left(457.73 \mathrm{~g} \mathrm{plant}^{-1}\right)$ after check genotype $\left(618.60 \mathrm{~g} \mathrm{plant}^{-1}\right)$. The highest root yield was found in BSP-12 (88.30 $\left.\mathrm{t} \mathrm{ha}^{-1}\right)$, planted on 10 November and the lowest yield was found in BSP-5 (22.53 t ha ${ }^{-1}$ ), planted on 10 October. BSP-12 was found the suitable genotype, under the planting dates in November, for their better growth and yield performance in acidic soil of Sylhet.

Keywords: Planting, Dates, Sweet, Potato.

Copyright @ 2020: This is an open-access article distributed under the terms of the Creative Commons Attribution license which permits unrestricted use, distribution, and reproduction in any medium for non-commercial use (NonCommercial, or CC-BY-NC) provided the original author and source are credited.

\section{INTRODUCTION}

Sweetpotato (Ipomoea batatas L.) is a dicotyledonous plant that belongs to family, Convolvulaceae. It is an extremely versatile, delicious and widely distributed tropical tuber crop, grown in different ecological zones due to its adaptability to varying climatic and edaphic conditions. Among the root and tuber crops grown in the world, sweetpotato ranks second after cassava [1]. It is the sixth most important food crop in the world [2]. The average storage root yields in Bangladesh are very low as compared to those of other tropical and subtropical countries [3] due to cultivation of local and poor quality indigenous sweetpotato genotypes. According to Agricultural Statistics 2015, the average area for sweetpotato production is 25 thousand ha and average production is 254,633 MT. In Sylhet region, sweetpotato is cultivated in 1100 ha land and average production is 5977 MT in a year [4]. The crop takes around 90 to 180 days to become mature depending on cultivar and climatic conditions under dry land farming. Sweetpotato is grown in almost every location in Bangladesh but is intensively grown in Cumilla, Kishoreganj, Jamalpur, Barishal, Patuakhali, Dhaka and Noakhali. In Bangladesh, Sweetpotato is generally harvested during March to May when cereal supply, like rice, begins to dwindle. Sweetpotato plays an important role to compensate the demand of cereals of the indigent people of Bangladesh. It is consumed in several forms, with the tuber being consumed raw, boiled, as porridge or pounded into flour. Sweetpotato varies in flesh and skin colour, texture, leaf shape and vine length. Sweetpotato can be processed into starch for industrial products due to its high starch content. it is a rich source of dietary fibre, antioxidants, vitamins, and minerals [5]. The area, total production and yield 
of sweetpotato in Bangladesh have not been changed much during the last decade. Production will be high if high yielding genotypes are grown in a suitable soil and climatic condition. There is a need to evaluate the performance of sweetpotato cultivation under different planting dates and effect on the yield in order to minimize the effects of natural drought associated with planting dates and to know about the highest yield. It would generate information useful for advising farmers on optimal planting dates for the different crops in order to maximize yield. However, a clear recommendation on suitable planting time for the BARI-released varieties in relation to the growth and yield along with economic return in Sylhet region had not yet been done. For this reason, the study was conducted to know the effect of optimum planting dates on growth, phenology and yield of sweetpotatoes.

\section{MATERIALS AND METHODS}

The experiment was laid out in a Randomized Complete Block Design (RCBD). The whole field was divided into 3 blocks for 3 replications ( 3 blocks $\times 6$ unit plots $\times 3$ replications). The size of the subplot was of $1.8 \mathrm{~m} \times 1.2 \mathrm{~m}$. The adjacent blocks, plots and neighboring unit plots was separated by $1.0 \mathrm{~m}, 0.8 \mathrm{~m}$, $0.60 \mathrm{~m}$ respectively. Sweetpotato vine was planted in lines with a spacing of $0.60 \mathrm{~m}$ and $0.30 \mathrm{~m}$ for row to row and plant to plant, respectively. Sixty days old vine cuttings varied from 30 to $40 \mathrm{~cm}$ long with 6 to 7 nodes off different genotypes of sweetpotato (BSP-1, BSP-2, BSP-5, BSP-8, BSP-12) and Local-6 (as check genotype) were planted on the ridge of the lines. Planting distance between the rows were $60 \mathrm{~cm}$ and plants $30 \mathrm{~cm}$. The cutting of vine was planted done on 10 October, 10 November and 10 December in 2016. The crop was harvested at full maturity at 150 DAP in case of every planting. Leaves, roots, storage roots and vines were collected in the paper bag and were brought freshly in the laboratory to take fresh weight. After taking fresh weight, except storage roots these were put in the oven for drying to take dry weight. Sweetpotatoes were sliced with the sharpen knife and kept into the oven at $80^{\circ} \mathrm{C} \pm 2^{\circ} \mathrm{C}$ for three days. Vine number \&length (both primary \& secondary) and leaf length and breadth were recorded. Total leaf area was calculated by using the following formula

$$
\text { Total leaf area }=(\text { leaf length } \times \text { leaf breadth }) \times \text { total leaf }
$$

Leaf weight, stem weight, fibrous root weight, storage root weight and total weight of plant were measured and recorded. Number of storage roots, diameter of storage roots at harvest $(\mathrm{cm})$, length of storage roots at harvest $(\mathrm{cm})$ and Yield of storage root $\mathrm{ha}^{-1}$ were measured and recorded. The means for all the treatments were calculated and analysis of variance of all the characters studied was performed by $\mathrm{F}$-test. The significance of the difference between the pair of means was evaluated by Duncan's Multiple Range Test (DMRT) using R programme in the computer.

\section{RESULTS}

Vine number and vine length (both primary and secondary) leaf number, length, breadth and total leaf area varied significantly at $\mathrm{p} \leq 0.05$ under different planting dates (Table 1). The maximum number of primary vine was found in BSP-5 (9.00) at planting on November and in Local-6 (10.33) planted on 10
December. BSP-5 $(360.00 \mathrm{~cm})$ on 10 October recorded the highest primary vine length and BSP-12 $(45.40 \mathrm{~cm})$ on 10 November was found the smallest primary vine length. In case of secondary vine length, BSP-12 $(166.00 \mathrm{~cm})$ on 10 Oct. showed the maximum result and BSP-12 $(21.33 \mathrm{~cm})$ on 10 November showed the lowest result. The genotype BSP-5 (332.67) planted on 10 November showed the maximum number of leaf and BSP-5 (70.00) planted on October showed the minimum number of leaf. The genotype BSP-2 (11.20 $\mathrm{cm})$ on 10 October showed the maximum leaf length and BSP-1 $(4.90 \mathrm{~cm})$ on 10 October showed the lowest leaf length. The highest leaf breadth was found in BSP$1(6.80 \mathrm{~cm})$ on 10 December and the lowest leaf breadth in BSP-1 $(4.10 \mathrm{~cm})$ on 10 October. In case of total leaf area, BSP-5 $\left(13727 \mathrm{~cm}^{2}\right.$ plant $\left.^{-1}\right)$ on the planting time 10 November showed the maximum result and BSP-1 $\left(1767.20 \mathrm{~cm}^{2}\right.$ plant $\left.{ }^{-1}\right)$ on the planting time 10 November showed the lowest result. 
Sumi Dash et al., Sch J Agric Vet Sci, Feb, 2020; 7(2): 47-55

Table-1: Variation in morphological characteristics of sweetpotato genotypes under different planting dates

\begin{tabular}{|c|c|c|c|c|c|c|c|c|c|}
\hline \multicolumn{2}{|c|}{$\begin{array}{ll}\text { Genotypes } & \times \\
\text { Planting time } & \end{array}$} & \multirow{2}{*}{$\begin{array}{l}\begin{array}{l}\text { Primar } \\
\text { Vine } \\
\text { number }\end{array} \\
5 \pm 0.12 \text { ef }\end{array}$} & \multirow{2}{*}{$\begin{array}{l}\begin{array}{l}\text { Secondar } \\
\text { vine } \\
\text { number }\end{array} \\
\begin{array}{c}13.03 \pm 0.4 \\
3 \mathrm{c}-\mathrm{e}\end{array}\end{array}$} & \multirow{2}{*}{$\begin{array}{l}\begin{array}{l}\text { Primary } \\
\text { vine length }\end{array} \\
135.2 \pm 3.98 \mathrm{e}\end{array}$} & \multirow{2}{*}{$\begin{array}{l}\begin{array}{l}\text { Secondary } \\
\text { Vine length }\end{array} \\
70.4 \pm 3.1 \mathrm{~d} \\
\end{array}$} & \multirow{2}{*}{$\begin{array}{c}\text { leaf } \\
\text { number }\end{array}$} & \multirow{2}{*}{$\begin{array}{l}\begin{array}{l}\text { Leaf } \\
\text { Breadth } \\
\text { (cm) }\end{array} \\
4.1 \pm 0.12 \mathrm{k}\end{array}$} & \multirow{2}{*}{$\begin{array}{c}\begin{array}{c}\text { leaf length } \\
(\mathrm{cm})\end{array} \\
4.9 \pm 0.12 \mathrm{j}\end{array}$} & \multirow{2}{*}{$\begin{array}{c}\begin{array}{c}\text { Total leaf area } \\
\left(\mathrm{cm}^{2} \text { plant }^{-\mathbf{1}}\right)\end{array} \\
1767.2 \pm 45.061\end{array}$} \\
\hline & $\begin{array}{l}10 \text { Oct. } \\
2016\end{array}$ & & & & & & & & \\
\hline \multirow[t]{3}{*}{$\begin{array}{r}\text { BSP- } \\
1 \\
\end{array}$} & $\begin{array}{l}10 \text { Nov. } \\
2016\end{array}$ & $5 \pm 0.29$ ef & $15 \pm 1.15 \mathrm{c}$ & $\begin{array}{c}141.33 \pm 3.18 \\
\text { de }\end{array}$ & $27.63 \pm 1.2 \mathrm{~g}$ & $242 \pm 3.4 \mathrm{~b}$ & $\begin{array}{l}5.3 \pm 0.07 \\
\text { f-h }\end{array}$ & $\begin{array}{l}6.37 \pm 0.08 \\
\mathrm{gh}\end{array}$ & $\begin{array}{l}8154.27 \pm 197.14 \\
\text { c }\end{array}$ \\
\hline & $\begin{array}{l}10 \text { Dec. } \\
2016\end{array}$ & $\begin{array}{c}9.33 \pm 0.88 \\
\mathrm{ab}\end{array}$ & $\begin{array}{l}9.33 \pm 0.88 \\
\text { fg }\end{array}$ & $\begin{array}{c}83.67 \pm 4.91 \\
\text { gh }\end{array}$ & $54 \pm 3.79 \mathrm{e}$ & $135.67 \pm 3.48 \mathrm{e}$ & $6.8 \pm 0.21 \mathrm{a}$ & $8.5 \pm 0.12 \mathrm{c}$ & $\begin{array}{l}7853.5 \pm 321.13 \\
\mathrm{~cd}\end{array}$ \\
\hline & $\begin{array}{l}10 \text { Oct. } \\
2016\end{array}$ & $2 \pm 0.12 \mathrm{~h}$ & $6 \pm 0.12 \mathrm{i}$ & $94 \pm 2.89 \mathrm{~g}$ & $90.3 \pm 3.00 \mathrm{c}$ & $112 \pm 1.73 \mathrm{f}$ & $\begin{array}{l}5.9 \pm 0.12 \\
\text { cd }\end{array}$ & $11.2 \pm 0.12 \mathrm{a}$ & $7383.1 \pm 46.96 \mathrm{c}-\mathrm{e}$ \\
\hline \multirow[t]{3}{*}{$\begin{array}{r}\text { BSP- } \\
2 \\
\end{array}$} & $\begin{array}{l}10 \text { Nov. } \\
2016\end{array}$ & $\begin{array}{c}6.97 \pm 0.26 \\
\mathrm{c}\end{array}$ & $4 \pm 0.17 \mathrm{ij}$ & $\begin{array}{c}12.27 \pm 0.26 \\
\mathrm{~m}\end{array}$ & $25.97 \pm 0.60 \mathrm{~g}$ & $135 \pm 2.89 \mathrm{e}$ & $\begin{array}{l}6.13 \pm 0.09 \\
\text { bc }\end{array}$ & $7.97 \pm 0.14 \mathrm{~d}$ & $6605 \pm 354.32$ ef \\
\hline & $\begin{array}{l}\text { 10 Dec. } \\
2016\end{array}$ & $\begin{array}{c}6.6 \pm 0.31 \\
\mathrm{~cd}\end{array}$ & $\begin{array}{c}5.5 \pm 0.29 \\
\text { ij }\end{array}$ & $\begin{array}{c}117.67 \pm 2.60 \\
\mathrm{f}\end{array}$ & $96.67 \pm 6.94 b c$ & $89 \pm 2.08 \mathrm{~g}$ & $\begin{array}{l}6.53 \pm 0.20 \\
a b\end{array}$ & $7.53 \pm 0.15 \mathrm{e}$ & $\begin{array}{l}4391.47 \pm 294.65 \\
\text { gh }\end{array}$ \\
\hline & $\begin{array}{l}10 \text { Oct. } \\
2016\end{array}$ & $2 \pm 0.12 \mathrm{~h}$ & $3 \pm 0.17 \mathrm{j}$ & $360 \pm 2.89 \mathrm{a}$ & $77.67 \pm 2.60 \mathrm{~d}$ & $70 \pm 3.46 \mathrm{~h}$ & $\begin{array}{l}5.5 \pm 0.06 \\
d-f\end{array}$ & $\begin{array}{l}10.73 \pm 0.12 \\
b\end{array}$ & $\begin{array}{l}4121.47 \pm 117.02 \\
\text { hi }\end{array}$ \\
\hline \multirow[t]{3}{*}{$\begin{array}{r}\text { BSP- } \\
5 \\
\end{array}$} & $\begin{array}{l}10 \text { Nov. } \\
2016\end{array}$ & $9 \pm 0.17 b$ & $\begin{array}{c}12 \pm 0.17 \\
\text { d-f }\end{array}$ & $185 \pm 4.04 \mathrm{c}$ & $28 \pm 1.73 \mathrm{~g}$ & $332.67 \pm 7.86 \mathrm{a}$ & $\begin{array}{l}5.37 \pm 0.09 \\
\mathrm{e}-\mathrm{g}\end{array}$ & $\begin{array}{l}7.67 \pm 0.09 \\
\text { de }\end{array}$ & $\begin{array}{l}13727.6 \pm 517.09 \\
\mathrm{a}\end{array}$ \\
\hline & $\begin{array}{l}\text { 10 Dec. } \\
2016\end{array}$ & $\begin{array}{c}5.8 \pm 0.42 \\
\mathrm{de}\end{array}$ & $\begin{array}{c}6.33 \pm 0.33 \\
\mathrm{hi}\end{array}$ & $176 \pm 3.06 \mathrm{c}$ & $101.33 \pm 4.48 b$ & $106 \pm 4.93 \mathrm{f}$ & $\begin{array}{l}5.57 \pm 0.15 \\
\text { d-f }\end{array}$ & $\begin{array}{l}6.53 \pm 0.19 \\
\text { fg }\end{array}$ & $\begin{array}{l}3868.67 \pm 388.61 \\
h-j\end{array}$ \\
\hline & $\begin{array}{l}10 \text { Oct. } \\
2016\end{array}$ & $3 \pm 0.12 \mathrm{gh}$ & $\begin{array}{l}11.07 \pm 0.1 \\
2 \mathrm{e}-\mathrm{g}\end{array}$ & $\begin{array}{c}151.67 \pm 2.60 \\
\mathrm{~d}\end{array}$ & $96.3 \pm 1.10 \mathrm{bc}$ & $78 \pm 4.62 \mathrm{gh}$ & $\begin{array}{l}4.9 \pm 0.12 \\
\text { hi }\end{array}$ & $6.5 \pm 0.12 \mathrm{fg}$ & $\begin{array}{l}2488.33 \pm 161.40 \\
\mathrm{k} 1\end{array}$ \\
\hline \multirow[t]{3}{*}{$\begin{array}{r}\text { BSP- } \\
8 \\
\end{array}$} & $\begin{array}{l}10 \text { Nov. } \\
2016\end{array}$ & $\begin{array}{c}7.03 \pm 0.15 \\
\mathrm{c} \\
\end{array}$ & $\begin{array}{c}11.03 \pm 0.0 \\
9 \mathrm{e}-\mathrm{g}\end{array}$ & $70.67 \pm 1.07 \mathrm{ij}$ & $54.4 \pm 2.28 \mathrm{e}$ & $245 \pm 2.89 \mathrm{~b}$ & $\begin{array}{l}5.07 \pm 0.15 \\
g-i\end{array}$ & $7.5 \pm 0.12 \mathrm{e}$ & $\begin{array}{l}9340.53 \pm 478.54 \\
\mathrm{~b}\end{array}$ \\
\hline & $\begin{array}{l}\text { 10 Dec. } \\
2016\end{array}$ & $\begin{array}{c}6.67 \pm 0.88 \\
\mathrm{~cd}\end{array}$ & $\begin{array}{c}9.33 \pm 2.91 \\
\mathrm{fg}\end{array}$ & $58 \pm 9.61 \mathrm{k}$ & $45.67 \pm 3.84 \mathrm{ef}$ & $153 \pm 4.36 \mathrm{~d}$ & $\begin{array}{l}5.77 \pm 0.32 \\
\text { c-e }\end{array}$ & $5.93 \pm 0.24 \mathrm{i}$ & $\begin{array}{l}5224.67 \pm 307.42 \\
\mathrm{~g}\end{array}$ \\
\hline & $\begin{array}{l}10 \text { Oct. } \\
2016\end{array}$ & $\begin{array}{c}4.13 \pm 0.09 \\
\text { fg }\end{array}$ & $\begin{array}{c}13.2 \pm 0.12 \\
\text { c-e }\end{array}$ & $\begin{array}{c}230.67 \pm 2.33 \\
b\end{array}$ & $166 \pm 5.77 \mathrm{a}$ & $119.67 \pm 6.06 \mathrm{f}$ & $\begin{array}{l}5.63 \pm 0.09 \\
\text { d-f }\end{array}$ & $\begin{array}{l}6.73 \pm 0.03 \\
\text { fg }\end{array}$ & $\begin{array}{l}4546.03 \pm 299.05 \\
\text { gh }\end{array}$ \\
\hline \multirow[t]{3}{*}{$\begin{array}{r}\text { BSP- } \\
12 \\
\end{array}$} & $\begin{array}{l}10 \text { Nov. } \\
2016\end{array}$ & $5 \pm 0.17$ ef & $9 \pm 0.12 \mathrm{gh}$ & $45.4 \pm 1.651$ & $21.33 \pm 0.66 \mathrm{~g}$ & $218.33 \pm 5.84 \mathrm{c}$ & $\begin{array}{l}4.87 \pm 0.18 \\
\mathrm{ij}\end{array}$ & $\begin{array}{l}6.63 \pm 0.09 \\
\text { fg }\end{array}$ & $\begin{array}{l}7073.13 \pm 542.83 \\
\text { d-f }\end{array}$ \\
\hline & $\begin{array}{l}10 \text { Dec. } \\
2016\end{array}$ & $\begin{array}{l}6.27 \pm 0.15 \\
\text { cd }\end{array}$ & $\begin{array}{l}14 \pm 0.58 \\
\mathrm{~cd}\end{array}$ & $\begin{array}{c}87.67 \pm 3.18 \\
\text { gh }\end{array}$ & $42.33 \pm 2.33 \mathrm{f}$ & $75 \pm 7.64 \mathrm{gh}$ & $\begin{array}{l}5.03 \pm 0.12 \\
\text { g-i }\end{array}$ & $7.97 \pm 0.15 \mathrm{~d}$ & $\begin{array}{l}3031.37 \pm 403.81 \\
\mathrm{jk}\end{array}$ \\
\hline & $\begin{array}{l}10 \text { Oct. } \\
2016\end{array}$ & $7 \pm 0.12 \mathrm{c}$ & $\begin{array}{c}18.2 \pm 1.56 \\
b\end{array}$ & $\begin{array}{c}60.33 \pm 1.82 \\
\mathrm{jk}\end{array}$ & $47.3 \pm 5.08 \mathrm{ef}$ & $157 \pm 3.46 \mathrm{~d}$ & $3.5 \pm 0.121$ & $\begin{array}{l}6.07 \pm 0.09 \\
\text { hi }\end{array}$ & $3332 \pm 84.85$ i-k \\
\hline \multirow[t]{2}{*}{$\begin{array}{r}\text { Local } \\
-6 \\
\end{array}$} & $\begin{array}{l}10 \text { Nov. } \\
2016\end{array}$ & $6 \pm 0.12 \mathrm{ce}$ & $\begin{array}{c}11 \pm 0.46 \\
\mathrm{e}-\mathrm{g}\end{array}$ & $81.17 \pm 1.45 \mathrm{~h}$ & $29.6 \pm 1.16 \mathrm{~g}$ & $238.1 \pm 1.21 \mathrm{~b}$ & $\begin{array}{l}3.37 \pm 0.09 \\
1\end{array}$ & $\begin{array}{l}7.77 \pm 0.09 \\
\text { de }\end{array}$ & $\begin{array}{l}6212.83 \pm 214.14 \\
\mathrm{f}\end{array}$ \\
\hline & $\begin{array}{l}10 \text { Dec. } \\
2016\end{array}$ & $\begin{array}{c}10.33 \pm 0.8 \\
8 \mathrm{a} \\
\end{array}$ & $\begin{array}{c}31.67 \pm 1.4 \\
5 \mathrm{a} \\
\end{array}$ & $\begin{array}{c}80.67 \pm 3.48 \\
\text { hi }\end{array}$ & $49.33 \pm 2.96 \mathrm{ef}$ & $\begin{array}{l}216.67 \pm 10.93 \\
\mathrm{c}\end{array}$ & $\begin{array}{l}4.47 \pm 0.14 \\
\mathrm{jk}\end{array}$ & $6.8 \pm 0.24 \mathrm{f}$ & $\begin{array}{l}6540.1 \pm 286.86 \\
\text { ef }\end{array}$ \\
\hline
\end{tabular}

In each column, figures having common letter(s) do not differ significantly at $\mathrm{p} \leq 0.05$ as per DMRT

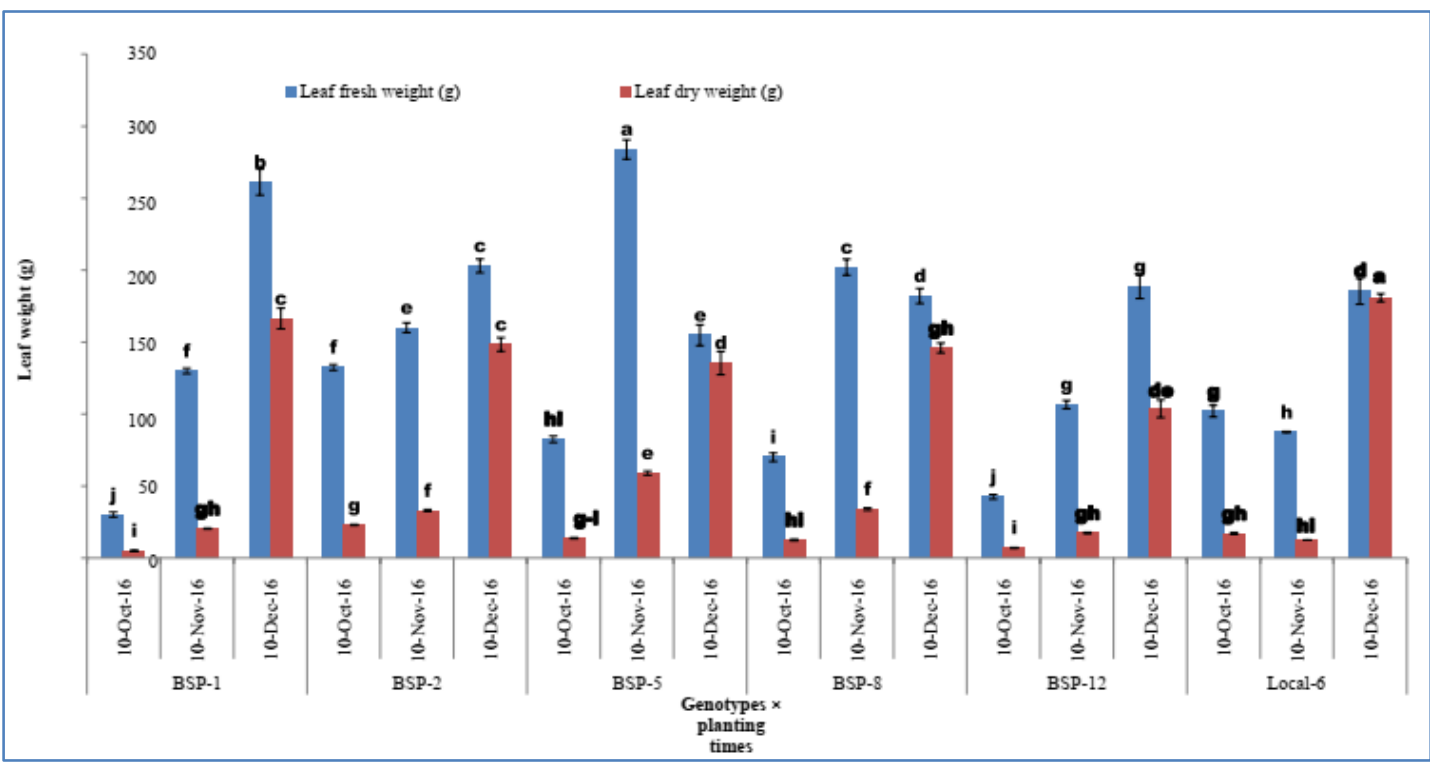

Fig-1: Effect of interaction on leaf weight of sweetpotato genotypes (Vertical bars represent SEM at $p \leq 0.05$ 


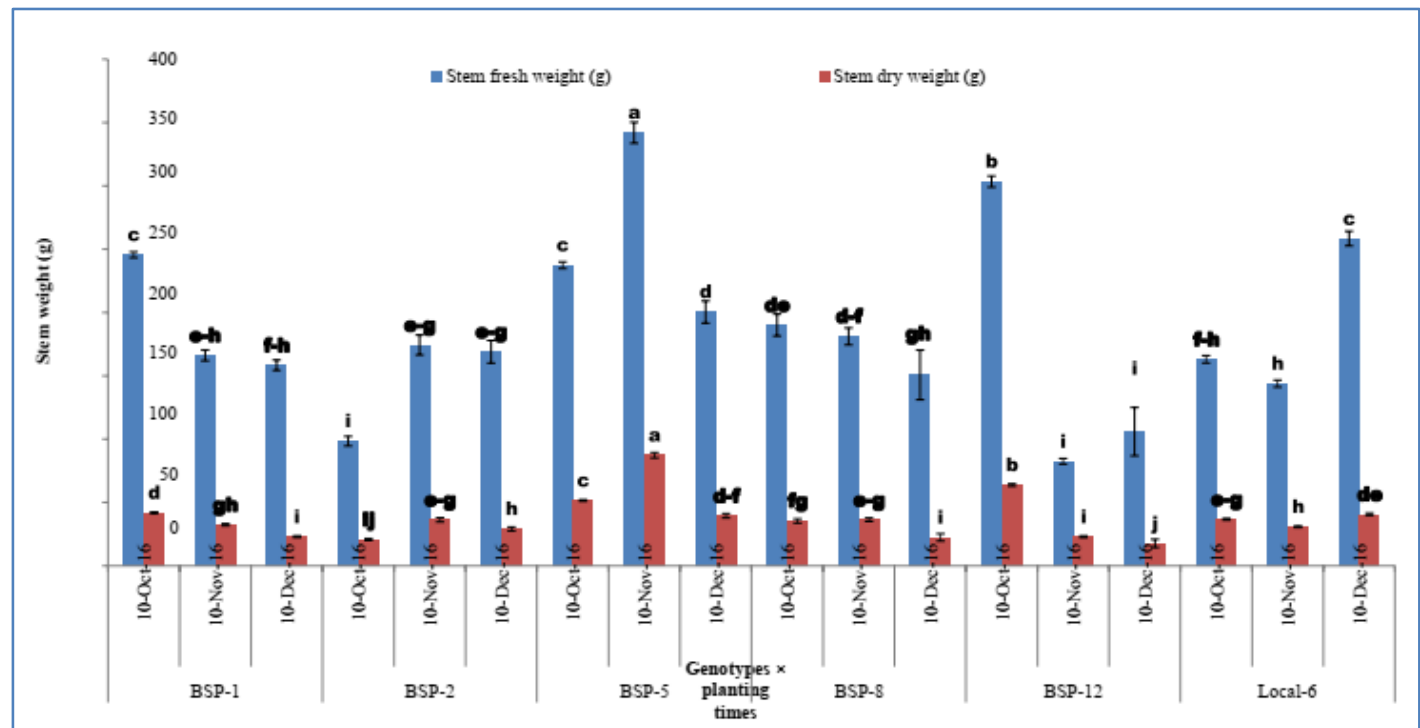

Fig-2: Effect of interaction on stem weight of sweetpotato genotypes (Vertical bars represent SEM at $\mathbf{p} \leq 0.05$ )

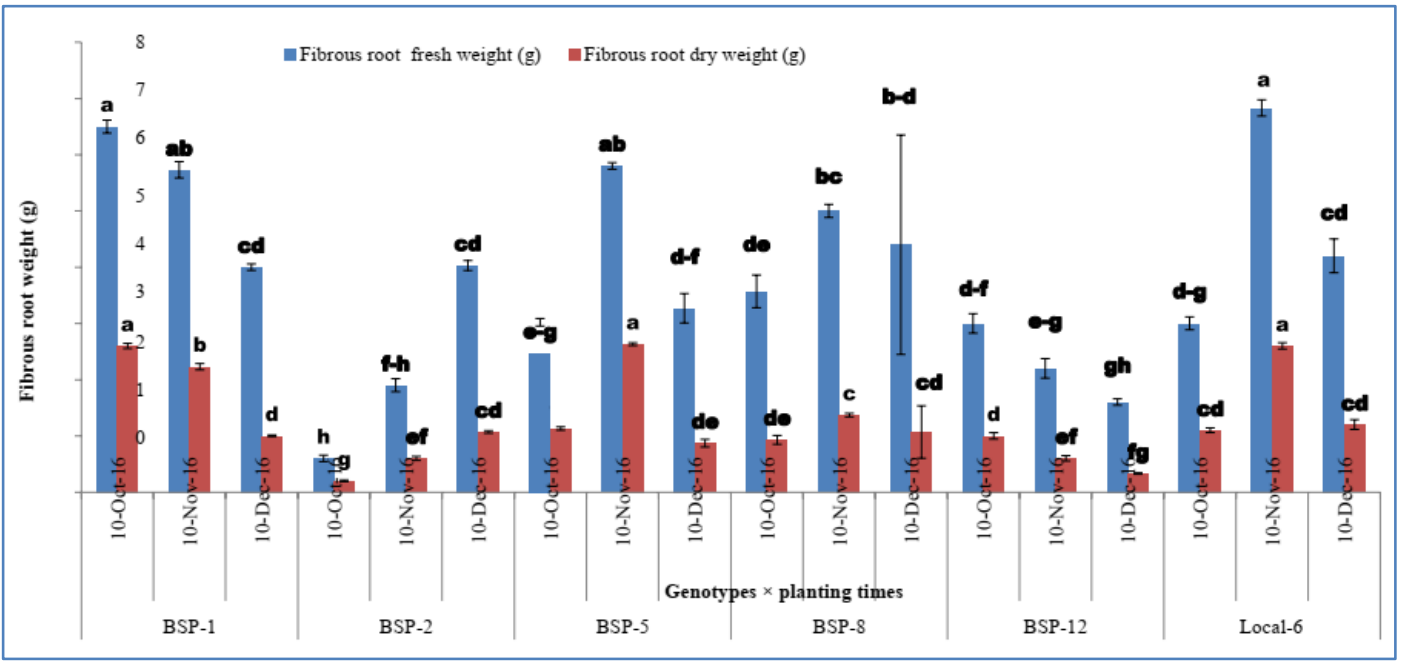

Fig-3: Effect of interaction on fibrous root weight of sweetpotato genotypes (Vertical bars represent SEM at $\mathbf{P} \leq \mathbf{0 . 0 5})$

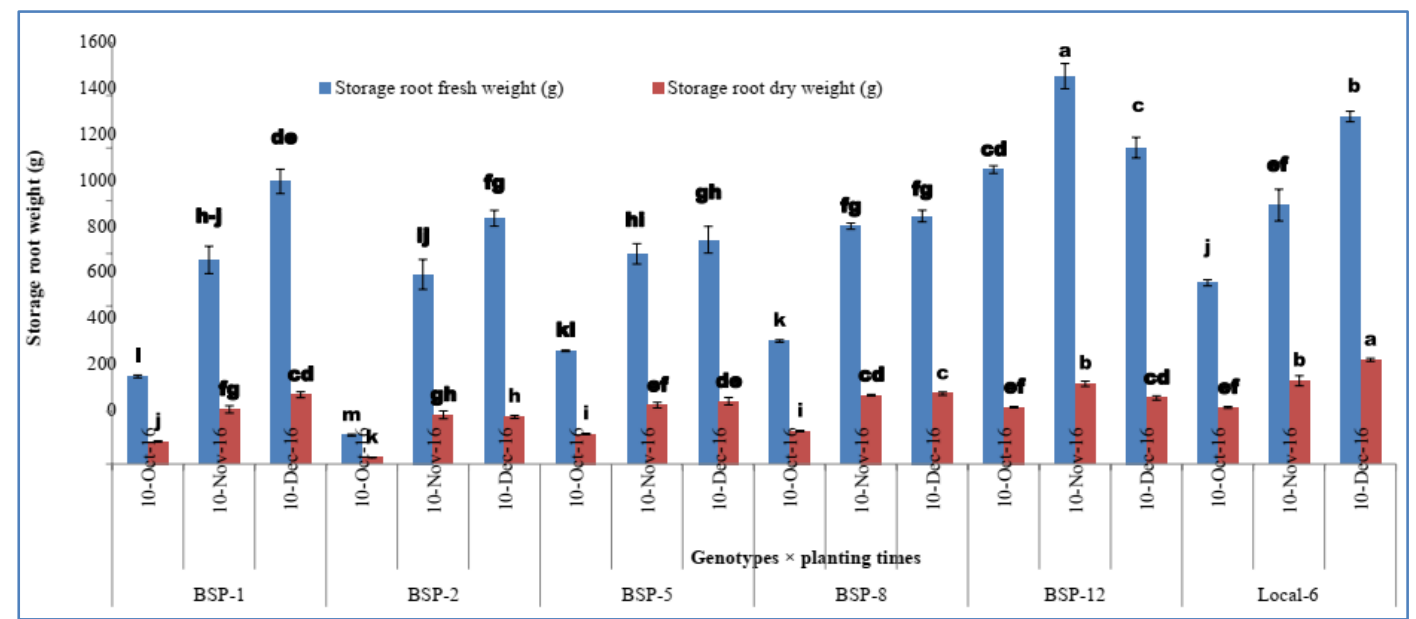

Fig 4: Effect of interaction on storage root weight of sweetpotato genotypes (Vertical bars represent SEM at $\mathrm{p} \leq \mathbf{0 . 0 5 )}$ 


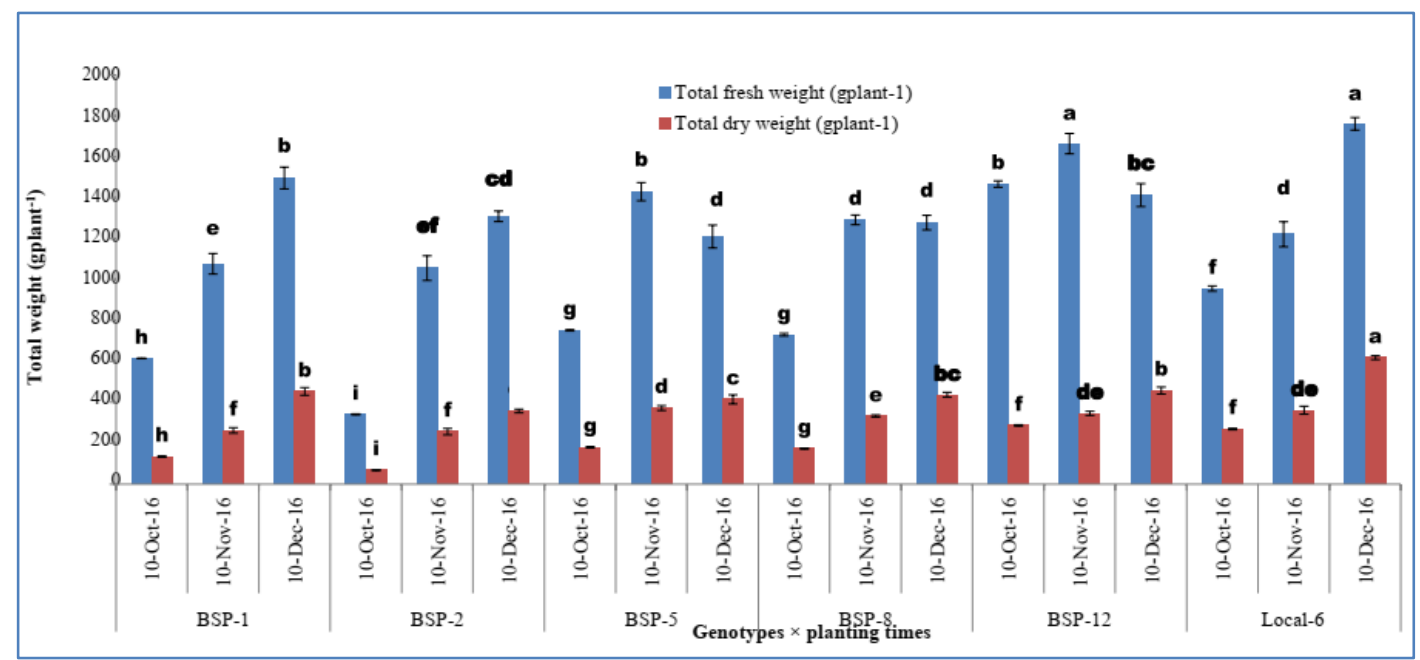

Fig-5: Effect of interaction on total weight of sweetpotato genotypes (Vertical bars represent SEM at $\mathbf{p} \leq 0.05$ )

Leaf weight, stem weight, fibrous root weight, storage root weight and total weight of plant varied significantly among the treatment combination at $\mathrm{p} \leq$ 0.05 . The highest fresh weight of leaf $(283.90 \mathrm{~g})$ was found in BSP-5 on the planting time 10 November and the lowest fresh weight $(30.10 \mathrm{~g})$ recorded in BSP-1 on 10 October. On the other hand, the maximum leaf dry weight of leaf $(188.67 \mathrm{~g})$ was found in BSP-1 on 10 October and minimum leaf dry weight of leaf was found in BSP-12 (12.50 g) on planting time 10 December after check genotype. BSP-5 (341.93 g) on 10 November planting time showed the highest stem fresh weight and BSP-12 (82.43 g) on 10 November planting time showed the lowest result. Again, BSP-5 $(87.20 \mathrm{~g})$ on 10 November showed the best stem dry weight and BSP-12 (17.57 g) on 10 December showed the lowest stem dry weight. BSP-1 $(6.50 \mathrm{~g})$ on 10 October planting time showed the maximum fibrous root fresh weight which is statistically similar to Local$6(6.83 \mathrm{~g})$ on 10 November and BSP-2 ( $0.60 \mathrm{~g})$ on 10 October planting time showed the lowest fibrous root fresh weight followed by 10 December. Again BSP-1 $(2.60 \mathrm{~g})$ on 10 October and Local-6 (2.60 g) on the planting time 10 November showed the best fibrous root dry weight and BSP-2 $(0.20 \mathrm{~g})$ on 10 October showed the lowest stem dry weight. The maximum storage root fresh weight was found in BSP-12 $(1473.33 \mathrm{~g})$ on the planting time 10 November and the lowest fresh weight observed in BSP-8 (467.33 g) on the planting time 10 October. On the other hand, the maximum storage root dry weight found in BSP-12 $(305.00 \mathrm{~g})$ on the planting time 10 November and minimum leaf dry weight found in BSP-2 (24.67 g) with planting time 10 October. BSP-12 (1664.57 g plant $^{-1}$ ) planted on 10 December showed the maximum total fresh weight and BSP-2 (341.30 $\mathrm{g} \mathrm{plant}^{-1}$ ) planted on 10 October showed the minimum total fresh weight. Again Local- 6 (618.60 g plant $\left.{ }^{-1}\right)$ on the planting time 10 December showed the highest total dry weight and BSP-2 (68.43 g plant-1) on 10 October showed the lowest total dry weight.

Number of storage root, length of storage root, diameter of storage root and yield of storage root varied significantly at $\mathrm{P} \leq 0.05$ under different planting time (Table 2). The maximum number of storage root found in BSP-1 (8.00) on 10 December. The minimum number of storage root observed in case of BSP-5 (4.17) on 10 December. BSP-1 (6.00) on 10 October, BSP-12 (6.00) on 10 December and Local-6 (5.83) on 10 October showed the statistically similar result. On the other hand, BSP-2 (5.57) on 10 November BSP-5 (5.50) on 10 October BSP-8 (5.37) on 10 October BSP 8 (5.57) on 10 November was also showed the statistically similar result. BSP-12 $(17.07 \mathrm{~cm})$ on 10 October showed the highest primary vine length followed by Local-6 $(20.67 \mathrm{~cm})$ and BSP-8 $(10.60 \mathrm{~cm})$ on 10 October showed the smallest storage root. The maximum diameter found in BSP-12 $(5.77 \mathrm{~cm})$ on the planting time 10 December and the minimum diameter found in the genotype BSP-5 $(3.57 \mathrm{~cm})$, planted on 10 October. Yield significantly varied from $88.30 \mathrm{t} \mathrm{ha}^{-1}$ to $22.53 \mathrm{t} \mathrm{ha}^{-1}$. BSP- $12\left(88.30 \mathrm{t} \mathrm{ha}^{-1}\right)$ on the planting time 10 November showed the maximum yield and BSP-5 $\left(22.53 \mathrm{t} \mathrm{ha}^{-1}\right)$ on 10 October showed the lowest yield. 
Table-2: Yield and yield attributing characters of sweetpotato genotypes under different planting dates

\begin{tabular}{|c|c|c|c|c|c|}
\hline \multicolumn{2}{|c|}{$\begin{array}{c}\text { Genotypes } \times \text { Planting } \\
\text { time }\end{array}$} & \multirow{2}{*}{$\begin{array}{c}\begin{array}{c}\text { Number of } \\
\text { storage root }\end{array} \\
6.00 \pm 0.58 \mathrm{c}-\mathrm{e}\end{array}$} & \multirow{2}{*}{$\begin{array}{c}\begin{array}{c}\text { Length of } \\
\text { storage root } \\
\text { (cm) }\end{array} \\
12.27 \pm 0.78 \mathrm{fg}\end{array}$} & \multirow{2}{*}{$\begin{array}{l}\begin{array}{l}\text { Diameter of } \\
\text { storage root } \\
\text { cm) }\end{array} \\
3.60 \pm 0.06 \mathrm{~h}\end{array}$} & \multirow{2}{*}{$\begin{array}{l}\begin{array}{l}\text { Yield } \\
\left.\text { tha }^{1}\right)\end{array} \\
33.03 \pm 1.34 \mathrm{i}\end{array}$} \\
\hline & 10 Oct. 2016 & & & & \\
\hline BSP-1 & 10 Nov. 2016 & $6.90 \pm 0.46$ a-d & $13.50 \pm 1.14 \mathrm{~d}-\mathrm{f}$ & $4.53 \pm 0.34 \mathrm{c}-\mathrm{g}$ & $51.10 \pm 2.45 \mathrm{f}$ \\
\hline & 10 Dec. 2016 & $8.00 \pm 0.29 \mathrm{a}$ & $13.33 \pm 0.74 \mathrm{~d}-\mathrm{g}$ & $5.00 \pm 0.15 \mathrm{a}-\mathrm{d}$ & $60.20 \pm 1.26 \mathrm{~cd}$ \\
\hline & 10 Oct. 2016 & $5.07 \pm 0.35 \mathrm{ef}$ & $11.50 \pm 0.40 \mathrm{fg}$ & $4.20 \pm 0.11$ e-h & $33.80 \pm 2.75 \mathrm{i}$ \\
\hline \multirow[t]{3}{*}{ BSP-2 } & 10 Nov. 2016 & $5.57 \pm 0.70 \mathrm{~d}-\mathrm{f}$ & $13.10 \pm 0.95 \mathrm{e}-\mathrm{g}$ & $4.03 \pm 0.24 \mathrm{f}-\mathrm{h}$ & $40.07 \pm 2.23 \mathrm{~h}$ \\
\hline & 10 Dec. 2016 & $6.17 \pm 0.27 \mathrm{~b}-\mathrm{e}$ & $13.77 \pm 0.87 \mathrm{c}-\mathrm{f}$ & $5.33 \pm 0.08 \mathrm{ab}$ & $48.87 \pm 2.18 \mathrm{fg}$ \\
\hline & 10 Oct. 2016 & $5.50 \pm 1.26 \mathrm{~d}-\mathrm{f}$ & $13.17 \pm 0.70 \mathrm{e}-\mathrm{g}$ & $3.57 \pm 0.02 \mathrm{~h}$ & $22.53 \pm 1.27 \mathrm{j}$ \\
\hline \multirow[t]{3}{*}{ BSP-5 } & 10 Nov. 2016 & $6.17 \pm 0.44$ b-e & $12.67 \pm 1.13 \mathrm{fg}$ & $3.77 \pm 0.11 \mathrm{gh}$ & $51.77 \pm 1.59 \mathrm{ef}$ \\
\hline & 10 Dec. 2016 & $4.1 \pm 0.17 \mathrm{f}$ & $13.17 \pm 0.71 \mathrm{e}-\mathrm{g}$ & $5.20 \pm 0.15 \mathrm{a}-\mathrm{c}$ & $50.97 \pm 1.87 \mathrm{f}$ \\
\hline & 10 Oct. 2016 & $5.37 \pm 0.88 \mathrm{~d}-\mathrm{f}$ & $10.60 \pm 1.14 \mathrm{~g}$ & $4.33 \pm 0.11 \mathrm{~d}-\mathrm{h}$ & $28.43 \pm 2.59 \mathrm{i}$ \\
\hline \multirow[t]{3}{*}{ BSP-8 } & 10 Nov. 2016 & $5.57 \pm 0.55 \mathrm{~d}-\mathrm{f}$ & $11.33 \pm 1.33 \mathrm{fg}$ & $4.83 \pm 0.34 \mathrm{~b}-\mathrm{e}$ & $57.27 \pm 2.28 \mathrm{de}$ \\
\hline & 10 Dec. 2016 & $7.33 \pm 0.51 \mathrm{a}-\mathrm{c}$ & $11.53 \pm 0.41 \mathrm{fg}$ & $4.60 \pm 0.07 \mathrm{~b}-\mathrm{f}$ & $45.03 \pm 1.68 \mathrm{gh}$ \\
\hline & 10 Oct. 2016 & $6.17 \pm 0.44 \mathrm{~b}-\mathrm{e}$ & $17.07 \pm 0.26 \mathrm{~b}$ & $4.43 \pm 0.72 \mathrm{c}-\mathrm{g}$ & $64.80 \pm 2.23 \mathrm{c}$ \\
\hline \multirow[t]{3}{*}{$\begin{array}{c}\text { BSP- } \\
12 \\
\end{array}$} & 10 Nov. 2016 & $7.67 \pm 0.48 a b$ & $15.83 \pm 0.42 \mathrm{~b}-\mathrm{e}$ & $4.73 \pm 0.23 \mathrm{~b}-\mathrm{f}$ & $88.30 \pm 0.80 \mathrm{a}$ \\
\hline & 10 Dec. 2016 & $6.00 \pm 0.19 \mathrm{c}-\mathrm{e}$ & $13.83 \pm 0.87 \mathrm{c}-\mathrm{f}$ & $5.77 \pm 0.32 \mathrm{a}$ & $73.60 \pm 1.78 \mathrm{~b}$ \\
\hline & 10 Oct. 2016 & $5.83 \pm 0.60$ c-e & $16.10 \pm 1.23 \mathrm{~b}-\mathrm{d}$ & $5.00 \pm 0.17 \mathrm{a}-\mathrm{d}$ & $39.57 \pm 1.32 \mathrm{~h}$ \\
\hline \multirow{2}{*}{$\begin{array}{l}\text { Local- } \\
6\end{array}$} & 10 Nov. 2016 & $5.10 \pm 0.22 \mathrm{ef}$ & $20.67 \pm 2.24 \mathrm{a}$ & $4.60 \pm 0.40$ b-f & $57.63 \pm 2.04 \mathrm{~d}$ \\
\hline & 10 Dec. 2016 & $5.47 \pm 0.44 \mathrm{~d}-\mathrm{f}$ & $16.53 \pm 0.64 \mathrm{bc}$ & $5.17 \pm 0.60$ a-c & $60.87 \pm 2.96 \mathrm{~cd}$ \\
\hline
\end{tabular}

In a year in each column, figures having common letter(s) do not differ significantly at $\mathrm{P} \leq 0.05$ as per

DMRT

\section{DISCUSSION}

Number of vines plant ${ }^{-1}$ reflects the overall plant growth. The number of vines plant ${ }^{-1}$ increased gradually from 45 DAP to until maturity in all growth stages of different sweetpotato genotypes. Growth stages differed significantly due to variety, different vine parts and in various interactions. The findings of the present experiment are in agreement with the findings of $[6,7]$ reported that number of vines plant ${ }^{-1}$ varied from 10.4 to 13.3 due to available nutrient present in soil [8] noticed that both the main effects of variety and planting density significantly influenced the number of branches plant ${ }^{-1}$ which could be mainly due to genetic differences in vigor among the variety. In October - March are the suitable times for getting longest primary vine of BSP-5 and November - April are the best times for getting maximum secondary vine of BSP-12. Some researchers also observed such variation in vine length in sweet potato [9] recorded the vine length of sweetpotato genotypes varied from 93.33 to $488.73 \mathrm{~cm}$ which was similar to the present findings [10] reported that vine length varying from 110 - 140 $\mathrm{cm}$ gave the best yield of sweetpotato those was similar to the present study [11]. Stated that the discrepancy in the number of leaves also results from diversity of the number of growing points (branches), rate of growth and leaf losses. The highest leaf number was found in BSP-5 at the planting time November when BSP-5 harvested at $150 \mathrm{DAP}$. [12] who stated that at harvest (145 DAP) the number of total unfolded leaves varied from 274.30 to 585.28 which was more or less similar to the present study.[13] reported that the harvesting at
175 DAP produced 196 to 399.17 number of total unfolded leaves which were also more or less similar to the present experimental findings. The breadth of leaf is important for the proper photosynthesis, which directly related to the yield. BSP-1 planted on December was produced the leaves with highest breadth. So, the genotype BSP-1 and the planting time December are the suitable for getting better leaf breadth in the present study. The present result was similar to the results obtained by [14]. According to present findings, the length of leaves ranged from $4.9 \mathrm{~cm}$ to $11.20 \mathrm{~cm}$. [15]. stated that length of leaves varied from 12 to $16.5 \mathrm{~cm}$, which was more or less similar with the present findings. The leaf length differed with the planting dates due to the variation of temperature, rainfall, sunlight etc. during the growth period. Leaf area varied along with the planting time. It may be due to the variation of weather condition and other environmental effects. BSP-5 $\left(13727 \mathrm{~cm}^{2}\right.$ plant $\left.^{-1}\right)$ was provided the greatest leaf area when it was planted on 10 November $[10,16,17]$ stated that the large leaf area combined with longer vine length give an advantage to sweetpotatoes during establishment in the field. A genotype with large leaf area can easily trap sunlight and hence carry out better photosynthesis required for carbohydrate synthesis in the plant than those with small leaf area [18] stated that leaf area leaf ${ }^{-1}$ ranged from 97.7 to $130.9 \mathrm{~cm}^{2}$ [19] reported that leaf area per meter squre of shairoyutaka (branching type) under high planting density increased progressively from the early stage (100 DAP) and slightly declined until 150 DAP. The best fresh weight was found in BSP-5 when 
it planted on 10 November. According to the present study, the BSP-5 is the suitable genotype for leaf fresh weight at the growing period November - April [20]. Stated that the fresh weight of leaves varied for soil salinity. The results of the present study vary with the findings of [20] perhaps due to a variation in soil acidity. On the other hand, BSP-1 was found as the best variety for leaf dry weight that was planted on 10 October [20] stated that the dry weight of leaves is varied from genotypes to genotypes. [12] found that the genotypes Doulatpuri produced the maximum dry matter in leaves whereas; the genotype $\mathrm{J} 9$ produced the minimum which findings are not so closely related to the present findings.

Fresh weight of stem varied significantly due to genotypes under three planting dates. It was found that BSP-5 produced the highest stem fresh weight at the planting time 10 November [21]. stated that the fresh weight of vine were 306 to $806 \mathrm{~g} \mathrm{plant}^{-1}$. Whereas, in case of stem dry weight, BSP-5 at the planting time November and BSP-12 at planting time December showed the highest dry matter and the lowest dry matter, respectively. The present findings are closely related to the results of [12].

From the present findings, it was found that the BSP-1 is the best genotype and October is the proper planting time for getting better stem fresh and dry weight. According to [7], the adventitious root fresh weight ranges from 1 to $2 \mathrm{~g}$. Variability of the nonstorage root weight depends on the better growth and development. Due to the poor growth and development the non- storage root the fresh weight might be varied. In case of dry weight of fibrous root, the present findings approximately similar to the findings of [12], who reported that the dry matter of fibrous root was $2.23 \%$ to $0.97 \%$. Dry matter was also higher due to poor growth of plants as the result of the storage root could not develop properly so the assimilate stores in non-storage roots. The fresh weight of storage root among the genotypes varied from $1473.33 \mathrm{~g}$ to 688.33 g. [22] stated that the fresh weight of storage roots plant $^{-1}$ varied widely in different genotypes. BSP-12, planted on November was produced the maximum fresh weight. On the other hand, BSP-12 produced the highest dry weight after the dry weight of Local-6 genotype and BSP-2 produced the least value. Due to the highest length and diameter of storage root, genotype BSP-12 produced the highest storage roots fresh weight plant ${ }^{-1}$. The results of present study are similar to the findings of [20]. The maximum storage root dry weight was found in BSP-12, planted on November, after Local-6 and minimum dry weight was found in BSP-2, planted in October. So the growing period November-April is the suitable for the storage root weights of BSP-12.
In case of the interaction of genotypes and planting dates, BSP-12 was produced the highest total fresh weight, planted in November. So from the present findings, ultimately BSP-12 may produce the highest dry matter partitioning [12] reported that the highest fresh weight plant $^{-1}$ was found in the genotype Kamala sundari and the lowest was found in the genotype Doulatpuri which was not so similar to the present findings. Due to the soil characteristics and weather condition the present result might be varied [13] also stated that plant fresh weight increased with the advancement of plant growth in all cultivars till the final harvest (175 DAP). Different cultivars produced the highest plant fresh weight at different harvests. From the present study the total dry weight ranges from 618.60 to 68.43 plant $^{-1}$ [12]. Reported that the total dry matter ranged from 114.15 to $231.68 \mathrm{~g}$. BSP-12 provided the highest total dry weight than the other genotypes, planted on December. BSP-12 is a suitable genotypes for the highest fresh and dry weights. Its may be due to the variation of temperature of different planting dates. Variations observed among the genotypes in respect of the number of storage root under different planting time.. According to the present study the number of storage root ranges from 8 to 4.17 [21]. stated that the storage roots number plant ${ }^{-1}$ varied from 4.70 to 11.6 which were more or less similar to the present findings. The results obtained from the present study are consistent with the results of [23] who stated that the highest number of storage roots plant ${ }^{-1}$ ranged from 7.9 and 8.4 in 2007. In 2008 it increased to the ranges from 8.1 to 9.0 [24]. Reported that the number of storage roots plant $^{-1}$ varied from 3.09 to 6.88 and it depends on the variety [13]. Showed that the storage roots plant ${ }^{-1}$ ranges from 7.5 to 2.8 . BSP-1 was recorded the genotype which gave the maximum number of storage root (8.00) when it was planted on the month of December. This might be due to the variation of genetic makeup of the different sweetpotato genotypes. The length of storage root ranges from 20.67 to $10.60 \mathrm{~cm}$ [13]. Showed that the length of the storage roots differed among the varieties. The findings of the present study closely related to the findings of [23] who reported that the length of storage root plant ${ }^{1}$ in two years $(2007,2008)$ ranges from 14.4 to 16.3 $\mathrm{cm}$. The results of present study should close relationship to the results of [13] who found that the length was in the ranges from 15 to $18 \mathrm{~cm}$. According to [25], storage root length was ranged from 11.2 to 14 $\mathrm{cm}$. The storage root of BSP-12 was found longer then other genotypes, at the planting time 10 October 2016 after Local-6. The diameter of the storage roots varied due to the poor growth [26] who reported that diameter of storage root varied from variety to variety. The differences of storage roots characters are controlled by genetic makeup of the genotypes and it obviously vary from one genotype to another [13] stated that diameter of sweetpotato storage roots varied from 3.0 to $3.83 \mathrm{~cm}$. From this finding, it was clearly found that BSP-12 which was planted in December recorded the highest 
diameter. According to present finding, BSP-12 is the the best genotype among the other five. The present findings are more or less related to the report of [27] who stated that the yield of storage root ranged from 44.5 to 56.5 ton $\mathrm{ha}^{-1}$. [28]. Obtained the yield from 12 sweetpotato genotypes ranging from 14.34 to $55.63 \mathrm{tha}$ 1 [29]. Obtained the yield of sweetpotato genotypes ranges from 20.93 to $40.41 \mathrm{t} \mathrm{ha}^{-1}$. Hoque obtained the yield of eight sweetpotato genotypes ranging from 10.08 to $32.79 \mathrm{t} \mathrm{ha}^{-1}$. Significant variations among the genotypes were noticed may be due to the adoption of proper cultural management techniques [29] observed in field trials in rabi (winter), vines of sweetpotatoes cv. Tripti and a local cultivar were cut 95 - 155 days after planting (DAP). Fodder yields increased with delay in cutting. Tubers yields were highest in the uncut control, but did not differ significantly from storage root yields ranges from 22 to $25 \mathrm{t} \mathrm{ha}^{-1}$ at $125 \mathrm{DAP}$. Tripti gave better tuber yields ( 25 to $27 \mathrm{t} \mathrm{ha}^{-1}$ ) than the local cultivar. It is suggested that fodder can be harvested from 125 DAP without adversely affecting storage root yield [30], observed sweetpotato genotypes at $90-135$ days after planting (DAP). Based on tuber yield, the genotypes were grouped into early, medium and late. When harvested at 105 DAP, genotypes yield was highest in X-5 and V-35 (mean 19.2 and $18.9 \mathrm{t} \mathrm{ha}^{-1}$, respectively), whereas at 135 DAP it was highest in Dergaon Red and S-107 (24.8 and 22.8 t ha-1, respectively).

\section{CONCLUSION}

It is concluded that, significant variation in relation to the morphological characters, dry matter partitioning and yield attributing characters was observed among the interaction between the genotypes at different planting dates. Though different cultivars showed varied performances in different parameters, the investigations suggest that among the six genotypes the BSP-12 produced the highest yield. So BSP-12 is very promising for better yield in the Sylhet region. Planting of the sweetpotato in November and December was found the more productive compared to October.

\section{REFERENCES}

1. Ray RC, Ravi V. Post-harvest spoilage of sweetpotato in tropics and control measures. Critical reviews in food science and nutrition. 2005 Oct 1;45(7-8):623-44.

2. Ahmed JS, Elias M, Mondal NI, Ullah MM. Socioeconomic study of sweet potato cultivation in selected area of Bangladesh. J. Root Crops. 1990;16:56-7.

3. Varma VS, Singh KP, Singh NK, Singh JR, Verma SP, Mishra S, Sahu MP, Kumari K, Ray R. Rajendra Shakarkand 35 and Rajendra Shakarkand 43: Two high yielding selections of sweet potato. Journal of Root Crops. 1994;20:15-9.

4. BBS. Database of Bangladesh Bureau of Statistics;2015.

5. FAOSTAT. (2013). Database of the Food and
Agriculture Organization of the United Nations.

6. Choudhury SH, Ahmed SU, Sharfuddin AF. Effect of number of nodes in different types of vine cuttings on the growth and yield of sweet potatoes. Bangladesh Horticulture. 1986;14(1):29-33.

7. Shen S, Xu G, Clements DR, Jin G, Chen A, Zhang F, Kato-Noguchi H. Suppression of the invasive plant mile-a-minute (Mikania micrantha) by local crop sweet potato (Ipomoea batatas) by means of higher growth rate and competition for soil nutrients. BMC ecology. 2015 Dec 1;15(1):1.

8. MEBRATU M, Dechassa N. SWEET POTATO [Ipomoea batatas (L.) lam] growth and yield as affected by planting density and cultivar in wolaita soddo, southern ethiopia (Doctoral dissertation, Haramaya University).

9. Siddique MA. Studies on the morphology, growth and yield of some sweet potato genotypes. M. Sc.(Agriculture) thesis, Dept. of Horticulture, Bangladesh Agricultural University, Mymensingh. 1985.

10. Kareem I. Effects of phosphorus fertilizer treatments on vegetative growth, tuberous yield and phosphorus uptake of sweet potato (Ipomoea batatas). African Journal of Agricultural Research. 2013;8(22):2681-4.

11. Somda ZC, Kays SJ. Sweet potato canopy architecture: Branching pattern. Journal of the American Society for Horticultural Science. 1990 Jan 1;115(1):33-8.

12. Haque AM. Study of important morphological features and yield of eight sweet potato genotypes. MS (Agriculture) Thesis, Dept. of Crop Botany, Bangladesh Agricultural University, Mymensingh. 2002.

13. Rashid MHA. Comparative growth and yield studies of some exotic and local cultivars of sweetpotato. MS thesis, Department of Crop Botany, Bangladesh Agricultural University, Mymensingh; 2002.

14. Farooque AM, Husain A. Studies on the comparative morphological characters and the yield of the seven varieties of sweet potato. Bangladesh Horticulture. 1973;1(2):37-44.

15. Saraswati P. Physiological and growth responses of selected sweet potato (Ipomoea batatas (L.) Lam.) cultivars to water stress (Doctoral dissertation, James Cook University).

16. Ahmed M, Nigussie-Dechassa R, Abebie B. Effect of planting methods and vine harvesting on shoot and tuberous root yields of sweet potato (Ipomoea batatas (L.) Lam.) in the afar region of Ethiopia. Afr. J. Agric. Res. 2012 Feb 12;7(7):1129-41.

17. Allemann J, Laurie SM, Thiart S, Vorster HJ, Bornman $\mathrm{CH}$. Sustainable production of root and tuber crops (potato, sweet potato, indigenous potato, cassava) in southern Africa. South African Journal of Botany. 2004 Mar 1;70(1):60-6.

18. Kathabwalika DM, Chilembwe EH, Mwale VM, Kambewa D, Njoloma JP. Plant growth and yield 
stability of orange fleshed sweet potato (Ipomoea batatas) genotypes in three agro-ecological zones of Malawi. Int. Res. J. Agric. Sci. Soil Sci. 2013 Nov;3(11):383-92.

19. Sulaiman H, Sasaki O. Studies on effect of planting density on the growth and yield of sweet potato (Ipomoea batatas Lam.). Memoirs of the Faculty of Agriculture-Kagoshima University (Japan). 2001.

20. Delowar HK and Hakim MA. Effect of salinity levels on the morpho-physiological characteristics and yield attributes of sweetpotato genotypes. Int. J. Sci. Res. 2014; 10, 929-934.

21. Uddin SK, Nazim M. Effect of different parts of vine on the growth and yield of the sweetpotato. MS thesis, Department of Crop Botany, Bangladesh Agricultural University, Mymensingh;2006.

22. Siddique MAR. Studies on the morphology, growth and yield of some sweetpotato genotypes. MS thesis, Department of Horticulture, Bangladesh Agricultural University, Mymensingh;2005.

23. Uwah DF, Undie UL, John NM, Ukoha GO. Growth and yield response of improved sweet potato (Ipomoea batatas (L.) Lam) varieties to different rates of potassium fertilizer in Calabar, Nigeria. Journal of agricultural Science. 2013 Jul $1 ; 5(7): 61$.
24. Rahman MM, Haque MA. Studies on the morphological characteristics, yield and nutritive value of seven varieties of sweetpotato. Bangladesh journal of Horticulture. 2003; 11(2): 1-8.

25. Sarkar SK, Kumar R, Jain BP. Productivity potential of sweetpotato cultivars in Bihar plateau. Joumal of Root Crops.1992; 18(2): 81-84.

26. Hossain MD. Study on growth, yield, consumer's preference and storage of 30 sweet potato (Ipomoea batatas Lam.) genotypes. MS Thesis, Department of Horticulture, Bangladesh Agricultural University, Mymensingh. 1995 pp. 33-58.

27. Ghosh SP, Ramanujam T, Jos JS, Moorthy SN and Nair RG 2008: Tuber Crops. Oxford and IBH Publishing Co. Pvt. Ltd. New Delhi.2008; 149-208.

28. Siddique MA, Hasanuzzaman ATM, Husain A. Growth and yield of "Three" high yielding sweetpotato genotypes, Bangladesh. Journal of Agriculture. 2008; 13(3): 139-145.

29. Uddin MK, Mahbub ASM, Alam MJ, Hoque AKMZ. Fodder yield and root yield of sweetpotato as affected by different dates of vine cutting and varieties. Bangladesh Joumal of Scientific and industrial Research.2004; 29(2):47-53.

30. Goswami RK. Maturity stage of sweetpotato during winter season. Journal of Root Crops.1995; 21 (2): 82-85. 